\title{
Genomics in Latin America: Reaching the Frontiers
}

\author{
Pablo D. Rabinowicz ${ }^{1}$ \\ Cold Spring Harbor Laboratory, Cold Spring Harbor, New York 11724, USA
}

When an undergraduate student in science from Latin America is asked about career goals, the answer will probably invoke dreams of using cutting-edge technologies to investigate the frontiers of science. For these students, the realities of life in their countries almost always reduce their options for achieving this goal to only one: Emigrate to a developed country. Although many of these countries produce numerous international scientific papers relative to their small research budget (Macilwain 1999a), their access to the latest-generation technology is fairly limited. This is particularly true in the field of genomics, in which the need for automated, high-throughput equipment raises the cost even more. However, when done wisely, genomics research and development has proven to be an affordable reality for developing countries. Choosing the right model organism, organizing laboratory networks instead of megalaboratories, and concentrating funding on one large project instead of splitting it among many smaller ones are the methods by which genomics is succeeding in Latin America. The need for training scientists in disease-endemic countries led the World Health Organization (WHO) to pledge almost US \$1 million to launch the Special Program for Research and Training in Tropical Diseases (TDR), which was the first broad genomic initiative involving Latin American countries. The goal of TDR was to analyze the genomes of three protozoan and two helminth parasites that seriously affect developing countries: Trypanosoma cruzi (Chagas disease), Trypanosmoa brucei (African sleeping sickness), Leishmania major (leishmaniasis), Burgia malayi (filariasis), and Schistosoma mansoni (Schistosomiasis). The TDR projects were meant to increase knowledge of the molecular biology of these parasites and were especially oriented toward the development of therapies, vaccines, and diagnostics. North-South and South-South collaboration networks were organized so that expertise and technology could be transferred and distributed throughout these networks (Degrave et al. 1997; Johnston et al. 1999). South American countries participate in three of the five networks (T. cruzi [http://www.dbbm.fiocruz.br/ TcruziDB/index.html], leishmania [http://www.ebi. ac.uk/parasites/leish.html], and schistosoma [http:// www.nhm.ac.uk/hosted_sites/schisto/index.html]),

\section{'Corresponding author.}

E-MAIL rabinowi@cshl.org; FAX (516)367-8369.

Article and publication are at www.genome.org/cgi/doi/10.1101/ gr.179501. together with many developed and developing countries around the world. Moreover, the T. cruzi network was coordinated by a South American investigator from the Institute of Technological Investigations at the National University of General San Martín (IIBUNSAM), Argentina (Trypanosoma cruzi Consortium 1997), and a modest Schistosoma EST sequencing project had begun earlier in Brazil (Pena 1996). After five years, most of the specific aims of these collaborative efforts were achieved. Now a number of resources are available for each parasite, including large insert libraries, EST and GSS sequence data, physical maps, and databases. These resources are distributed among the network participants and the community through the Web. WHO's funding for these initiatives was fairly limited and was intended to be the primer for obtaining additional funding from other agencies. Indeed, parasite full-genome sequencing projects are now supported as a consequence of these early efforts. A remarkable case is that of $T$. cruzi, a protozoan causing the Chagas disease, which chronically or fatally affects millions of people in South America. This parasite received little attention from funding agencies before the WHO decided to fund the genomics project. The investment proved to be successful, as sequencing and mapping data became available from the collaborative network (Ferrari et al. 1997; Verdún et al. 1998; Santos et al. 1999; Agüero et al. 2000; Porcel et al. 2000) and the goal of attracting more funding agencies to extend this research was achieved. Recently the National Institute of Allergy and Infectious Diseases (NIAID) from the National Institutes of Health (NIH) assigned a grant to the Institute of Genome Research (TIGR), the Seattle Biomedical Research Institute, and the University of Uppsala to sequence the $T$. cruzi genome. This outcome is fortunate for the $T$. cruzi research community because the availability of extensive genomic data will accelerate the development of therapeutic and diagnostic tools. Nevertheless, it highlights the usual governmental policy in developing countries: not to fund basic research unless an applicable product can be obtained in the short term. When basic research is in the area of genomics, it is even harder to convince the local funding agencies to devote a substantial fraction of the research and development budget to a single, but very large, basic project that would yield just the raw materials for the preferred applied research.

Preferential support for applied research seems to be the trend in the scientific funding policies of devel- 
oping countries. This makes sense, considering the large international public efforts to generate and release genomic data to the public. Why would it be worth devoting the small resources available in developing countries to joining in this effort when there are so many other health and environmental problems in the Third World to be taken care of? This "applied versus basic" argument has long been present and was raised again a few years after the beginning of the $T$. cruzi genome project (Trypanosoma cruzi Consortium 1997). Paradigmatically, in spite of their efforts, groups conforming the T. cruzi network could not obtain local funding to complete the genome sequence. As a consequence, the job ended up being done by labs in developed countries. For the supporters of the "applied" policy, proof of the wisdom of their argument was that even without cutting-edge technology and the full $T$. cruzi genomic sequence data, several South American countries have been recently declared free of Chagas disease (http://www.who.int/tdr/diseases/chagas/ default.htm).

However, biological diversity is too large to assume that all the valuable genetic information is already in public or private databases, and the value of genomics is not just in sequence information. It is also in the development of technology to generate and analyze genomic data, which in turn could lead to useful products. This was clearly seen by Brazilian scientists and policymakers from the state of São Paulo. In 1997, the state science funding agency of São Paulo (FAPESP) committed more than US \$11 million to completely and accurately sequence the genome of Xylella fastidiosa, a phytopathogen that threatens orange cultivation, a major industry within this region (Bonalumé 1997). The funding received by this project alone represented a substantial proportion of the entire Brazilian research budget. Nevertheless, this bacterium was deemed agriculturally and economically important enough to be worth the effort, although knowledge of its complete genetic information would not give any short-term applied benefit to citrus producers. Despite this, the São Paulo state citrus growers' association (Fundecitrus) also contributed US \$500,000 to the project (Macilwain 1999b), demonstrating their confidence that this basic research would eventually yield practical benefits for citrus production.

The significant amount of genomic information expected to come from the $X$. fastidiosa genome project has not been its only benefit. Thirty labs in the São Paulo region have been equipped and trained in stateof-the-art technology instead of creating a center dedicated to the project. These laboratories were organized as a network known as the virtual institute ONSA (http://watson.fapesp.br/genoma3.htm). The strategy proved very successful in getting the job done at a high standard of quality within the planned 2-yr timeframe, as well as achieving the physical map (Frohme et al. 2000; Xylella fastidiosa Consortium 2000). The success was far-reaching: As an immediate consequence, FAPESP raised its bet and increased funding for genomic projects. Now, three more bacterial phytopathogens are being sequenced in São Paulo (a grape strain of Xylella fastidiosa; Leifsonia xyli ssp. xyli, a sugarcane pathogen; and Xanthomonas citri, another citrus pathogen), and a call has been issued for proposals to sequence several more. Complex genomes, such as that of sugar cane, are also being analyzed by EST approaches in which other Brazilian states are participating. Expansion of genomics efforts outside São Paulo is being promoted by the federal government through the creation of more ONSA-like networks (Macilwain and Bonalume Neto 2000). The São Paulo initiative also gives an example of the technological development often derived from ongoing genomic projects. After being preliminarily assayed in the S. mansoni genome project in Brazil (Dias Neto et al. 1997), the ORESTES technique (open reading frame ESTs) became an optional approach for obtaining human EST sequences spanning the open reading frames (de Souza et al. 2000; Dias Neto et al. 2000).

Thus, the effort invested by Brazil is paying off. Having shown that Brazilian labs are up to date with genomic technology, the Federal University of Pelotas became a member of the International Rice Genome Sequencing Project (IRGSP; Eckardt 2000). But perhaps the most remarkable consequence of the Brazilian experience is the fact that funding for genomic projects in Brazil is now also coming from abroad. The United States Department of Agriculture (USDA) is financing one-half of the US $\$ 500,000$ that the sequencing of the grape strain of $X$. fastidiosa will cost, and the United States-based Ludwig Institute for Cancer Research is supplying one-half of the US \$10 million that ONSA will use to produce up to one million ESTs from human tumors.

All of these achievements have been celebrated in a range of media, from the covers of scientific journals to the New York Times, as well as in local newspapers and on television. In some cases, this might have offered a false image of abundance and prosperity in Brazilian science, which could compete with leading labs worldwide to attract young Latin American scientists. Several Brazilian scientists working either in Brazil or the United States disagree with this image of generalized scientific prosperity in their country (Hötzel 2000; Prolla 2000). But the unquestionable merit of the Brazilian endeavor is yielding invaluable fruits and will hopefully catalyze improvements in the country's scientific system.

Following the same track as Brazil, Mexico has also engaged in bacterial genomics. Two megaplasmids from the nitrogen-fixing bacterium Rhizobium etli have been sequenced, and the complete genome sequence is 
in the pipeline in the Center for Research in Nitrogen Fixation (CIFN; http://itzamna.cifn.unam.mx) at the National Autonomous University of Mexico (UNAM). Funding for these projects comes from the National Council for Research and Technology (CONACYT), which has also recently made a significant gamble in assigning a US \$2 million grant to the Center for Advanced Research Studies (CINVESTAV) to carry on a maize functional genomics project. This investment represents $2 \%$ of the country's current yearly research and development budget, comparable to the proportion of the United States National Science Foundation (NSF) budget assigned to new plant genomics projects in recent years. One goal of the maize functional genomics effort is to gather sequence information for agriculturally important maize genes. In this way, they can seek legal protection for genes particularly relevant to local production. Another goal is to train human resources in new technologies, now absent in the country, that in turn will allow the Mexican scientific community to participate in future postgenomic international projects.

Other countries, such as Argentina, are still discussing whether they should make real investments in genomics. Meanwhile, some researchers in these countries are trying to keep up with genomic technology by maintaining their participation in the international networks or by generating new lower-scale projects, such as the genomic analysis of the sunflower, which is being carried out by several groups at the National Institute of Agricultural Technology (INTA). These researchers have begun sequencing several thousand sunflower ESTs as well as constructing a BAC library and mapping the genome using several approaches $(\mathrm{N}$. Paniego, M. Echaide, M. Muñoz, L. Fernández, S. Torales, P. Faccio, I. Fuksan, M. Carrera, R. Zandomeni, E.Y. Suárez, and H.E. Hopp pers. comm.). Other research groups at the same institute in collaboration with the IIB-UNSAM carried out a medium-scale genomic sequencing project aiming at gene discovery in the cattle pathogen Brucella abortus (Sánchez et al. 2001). The IIB-UNSAM is now using internal money to pursue the genomic sequencing of Campylobacter fetus, another cattle pathogen.

Interestingly enough, the Max Planck Institute in Goettingen, Germany, has decided to support the creation of a center for genomics at the National University of La Plata. This initiative was launched together with the Association of Universities of the Montevideo Group (AUGM), which includes several South American countries. The joint initiative will represent an investment of several million dollars. By the end of 2001, when the center is expected to open, several research groups will be established and 25 people will be hired. Perhaps this will mark a change in Argentinean politics regarding investing in genomics.
There are certainly many young Latin American scientists willing to take open positions to work on genomics. This was evident by the 110 applications to participate in a recent practical course on genomic sequencing and annotation (http://www. hhmi.org/grants/international/educate/past.htm; http://genoma.dna.uba.ar:8080) held at the Institute for Research in Genetic Engineering and Molecular Biology (INGEBI), Buenos Aires, and organized by the US National Academies with funding from the Howard Hughes Medical Institute (HHMI) and the Argentinean-Brazilian Center for Biotechnology (CABBIO). Nineteen students from eight Latin American countries had a chance to experience high-throughput genomics and, perhaps more important, to interact with experts from leading institutions and companies like the Genome Sequencing Center at Washington University, Cold Spring Harbor Laboratory, the Microarray Database at the School of Medicine from Stanford University, the Ludwig Institute for Cancer Research, (São Paulo, Brazil) and Cereon Genomics (Cambridge, MA). Among the students, there were members of some Latin American laboratories that are beginning to get involved in genomic sequencing projects. Genomicsrelated events such as this course, which are thus far fairly unusual, constitute a way to train people and establish collaborations between Latin American laboratories and strong genomics institutions in neighbor or central countries.

Clearly, the importance of being part of the new era in biology is becoming more and more evident in Latin America. Successful examples have proven that it is possible to do genomics and that these efforts generate resources and expertise, promote technology transfer, allow participation in international initiatives, and attract funding. By no means will they immediately create a scientific paradise, but these early efforts are definitely helping Latin American countries to increase their scientific impact at the international level and to stop their brain drain. The generalization of these ideas might very well be the way for these countries to recover their scientific future: those rising students who emigrated in search of scientific frontiers.

\section{ACKNOWLEDGMENTS}

I thank Anamaria Camargo, Alberto Carlos Frashc, Mariano Levin, Jean Phillipe Vielle, Rolando Rivera-Pomar, Victor González, Esteban Hopp, and Michael Ronemus for supplying information and critical reading of the manuscript.

\section{REFERENCES}

Agüero, F., Verdún, R.E., Frasch, A.C.C., and Sánchez, D.O. 2000. Genome Res. 10: 1996-2005.

Bonalumé, R. 1997 Nature 389: 654

Degrave, W., Levin, M.J., da Silveira, J.F., and Morel, C.M. 1997. Mem. Inst. Oswaldo Cruz 92: 859-862. 
de Souza, S.J., Camargo, A.A., Briones, M.R., Costa, F.F., Nagai, M.A., Verjovski-Almeida, S., Zago, M.A., Andrade, L.E., Carrer, H., El-Dorry, H.F., et al. 2000. Proc. Natl. Acad. Sci. 97: 12690-12693.

Dias Neto, E., Garcia Correa, R., Verjovski-Almeida, S., Briones, M.R., Nagai, M.A., da Silva Jr., W., Zago, M.A., Bordin, S., Costa, F.F., Goldman, G.H., et al. 2000. Proc. Natl. Acad. Sci. 97: 3491-3496.

Dias Neto, E., Harrop, R., Correa-Oliveira, R., Wilson, R.A., Pena, S.D., and Simpson, A.J. 1997. Gene 186: 135-142.

Eckardt, N.A. 2000. The Plant Cell 12: 2011-2017.

Ferrari, I., Lorenzi, H., Santos, M.R., Brandariz, S., Requena, J.M., Schijman, A., Vazquez, M., da Silveira, J.F., Ben-Dov, C., Medrano, C., et al. 1997. Mem. Inst. Oswaldo Cruz 92: 843-852.

Frohme, M., Camargo, A.A., Heber, S., Czink, C., Simpson, A.J., Hoheisel, J.D., and de Souza, A.P. 2000. Nucleic Acids Res. 28: 3100-3104.

Hötzel, M.J. 2000. Nature 407: 834.

Johnston, D.A., Blaxter, M.L., Degrave, W.M., Foster, J., Ivens, A.C., and Melville, S.E. 1999. Bioessays 21: 131-147.

Macilwain, C. 1999a. Nature 398: A4-A5. 1999b. Nature 398: A16-A18.

Macilwain, C. and Bonalume Neto, R. 2000. Nature 407: 440.

Pena, S.D.J. 1996. Trends Biotechnol. 14: 74-77.

Porcel, B.M., Tran, A.N., Tammi, M., Nyarady, Z., Rydaker, M., Urmenyi, T.P., Rondinelli, E., Pettersson, U., Andersson, B., and Aslund, L. 2000. Genome Res. 10: 1103-1107.

Prolla T.A. 2000. Nature 406: 826

Sánchez, D.O., Zandomeni, R., Cravero, S., Verdún, R.E., Pierrou, E., Faccio, P., Diaz, G., Lanzavecchia, S., Agüero, F., Frasch, A.C.C., et al. 2001. Infect. Immun. 69: 865-868.

Santos, M.R., Lorenzi, H., Porcile, P., Carmo, M.S., Schijman, A., Brandao, A., Araya, J.E., Gomes, H.B., Chiurillo, M.A., Ramirez, J.L., et al. 1999. Genome Res. 9: 1268-1276.

Trypanosoma cruzi Genome Consortium. 1997. Parasitology Today 13: $16-22$.

Verdún, R.E., Di Paolo, N., Urmenyi, T.P., Rondinelli, E., Frasch, A.C.C., and Sánchez, D.O. 1998. Infect. Immun. 66: 5393-5398.

Xylella fastidiosa Consortium of the Organization for Nucleotide Sequencing and Analysis, São Paulo, Brazil. 2000. Nature 406: 151-157. 
Genome Research 11:319-324

\section{Genomics in Latin America: Reaching the Frontiers}

Pablo D. Rabinowicz

This paper should have been identified as a "Commentary" rather than as a "First Glimpses/Commentary." 


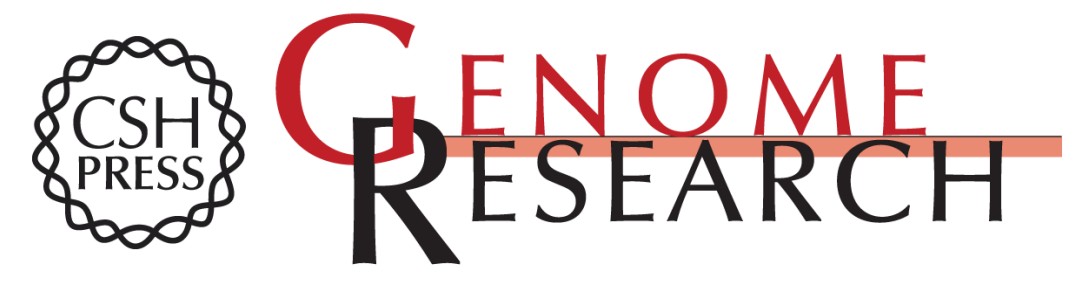

\section{Genomics in Latin America: Reaching the Frontiers}

Pablo D. Rabinowicz

Genome Res. 2001 11: 319-322

Access the most recent version at doi:10.1101/gr.179501

\section{Related Content}

Errata for vol. 11, p. 319

Genome Res. April, 2001 11: 631

References This article cites 21 articles, 8 of which can be accessed free at: http://genome.cshlp.org/content/11/3/319.full.html\#ref-list-1

Articles cited in:

http://genome.cshlp.org/content/11/3/319.full.html\#related-urls

\section{License}

Email Alerting

Receive free email alerts when new articles cite this article - sign up in the box at the Service top right corner of the article or click here.

\section{Affordable, Accurate Sequencing.}

To subscribe to Genome Research go to:

https://genome.cshlp.org/subscriptions 